\title{
The Data Gap: Promoting Analysis Of Exposure-Related Harms .
}

Caroline Cecot

Follow this and additional works at: https://via.library.depaul.edu/law-review

Part of the Law Commons

\section{Recommended Citation}

Caroline Cecot, The Data Gap: Promoting Analysis Of Exposure-Related Harms ., 69 DePaul L. Rev. (2020) Available at: https://via.library.depaul.edu/law-review/vol69/iss2/5

This Article is brought to you for free and open access by the College of Law at Digital Commons@DePaul. It has been accepted for inclusion in DePaul Law Review by an authorized editor of Digital Commons@DePaul. For more information, please contact digitalservices@depaul.edu. 


\title{
THE DATA GAP: PROMOTING ANALYSIS OF EXPOSURE-RELATED HARMS
}

\author{
Caroline Cecot*
}

\section{Contents}

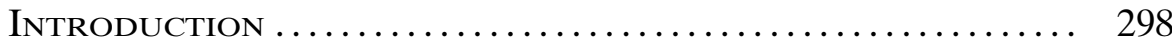

I. A Persistent Data Gap ................... 303

A. System Assumptions ......................... 304

B. Practical Challenges ........................ 306

C. Tort and Regulatory Limitations ............. 309

II. Tort Ways Forward .......................... 319

A. Burden-Shifting Approach to Causation............ 319

B. Court-Ordered Informational Monitoring ......... 322

1. Collateral Monitoring .................. 322

2. A New Tort Cause of Action for Monitoring.... 325

a. Defining the Cause of Action ........... 325

b. Considering Objections .................. 329

III. Regulatory Fixes . . . . . . . . . . . . . . . . . . . . . 332

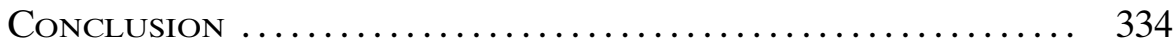

In the toxic tort context, both litigation and regulation require reliable scientific data to establish a causal connection between exposure to some substance and alleged harm before allowing recovery or mandating mitigation. On the one hand, it is important for litigation and regulation to be based on causal evidence of actual harms. Otherwise, these interventions could make society worse off by unduly limiting the availability of useful substances and diverting resources away from addressing true risks. On the other hand, for this system to comprehensively address all important environmental externalities, there must exist sufficient incentives to generate the data required for effective risk-management through litigation and regulation.

* Caroline Cecot is an Assistant Professor of Law at Antonin Scalia Law School at George Mason University. I am grateful to Yehonatan Arbel, Jake Byl, Joni Hersch, Benjamin McMichael, Jordan Neyland, Piotr Pilarski, Teddy Rave, Richard Revesz, Edward Richards, Anthony Sebok, Catherine Sharkey, and Adam Zimmerman for providing helpful reactions to this topic. I am also grateful to the Clifford Symposium at DePaul University for supporting this work and to participants for providing feedback. Dylan Campbell, Kate Gaziano, Briana McLeod, and Madeline Meckes provided excellent research assistance. 
This Article argues that, in many cases, the incentives are insufficient. When it comes to latent harms, in particular, scientific research evaluating causal links is challenging and expensive. Independent researchers, who require funding for their work, are unlikely to systematically analyze the effects of new substances. To date, there are thousands of unstudied substances in use.

Given the increasing importance of reliable scientific data for efficient risk management, it is time to evaluate all options for incentivizing its production in order to promote optimal deterrence in the toxic tort context. This Article proposes several ways to combat the persistent data lag, including changes to tort common law and regulation. Most controversially, it proposes a new tort cause of action for informational monitoring and analysis in some circumstances when there exist no reliable studies on the potential harm of a particular substance. A successful claim would lead to the establishment of a scientific panel, paid for by the defendant, to analyze and monitor the link between exposure to the substance and subsequent health outcomes.

\section{INTRODUCTION}

In 2001, a group of West Virginia residents sued E.I. Du Pont de Nemours and Company (DuPont) alleging that the company contaminated the group's water supply with a substance referred to as C-8. ${ }^{1}$ The group blamed C-8 for more than thirty different diseases, including asthma, high cholesterol, kidney cancer, and birth defects. ${ }^{2} \mathrm{Du}-$ Pont had used C-8 in its manufacturing process for Teflon and other related products since the $1950 \mathrm{~s}$, but there was little scientific evidence available about the long-term effects of exposure to C-8. ${ }^{3}$ In particular, there were no epidemiological studies linking the substance to any specific condition, the company never tested the long-term effects of exposure to the substance, other researchers had not studied this is-

1. See In re E. I. Du Pont De Nemours \& Co. C-8 Pers. Injury Litig., No. 2:13-CV-170, 2016 WL 659112, at*1 (S.D. Ohio Feb. 17, 2016); Leach v. E.I. Du Pont de Nemours \& Co., No. 01-C608, 2002 WL 1270121, at*3 (W. Va. Cir. Ct. Apr. 10, 2002). C-8, also known as perfluorooctanoic acid, is part of a chemical family of manmade substances. For a comprehensive description of DuPont's actions, the litigation, and the evidence generated by the settlement, see Laura Hall, Alastair Iles \& Rachel Morello-Frosch, Litigating Toxic Risks Ahead of Regulation: Biomonitoring Science in the Courtroom, 31 Stan. EnVTL. L.J. 3, 19-24, 38-42 (2012); Thomas O. McGarity, The Complementary Roles of Common Law Courts and Federal Agencies in Producing and Using Policy-Relevant Scientific Information, 37 EnvTL. L. 1027, 1038-49 (2007).

2. In re E. I. Du Pont, $2016 \mathrm{WL}$ 659112, at*3.

3. See id. at $* 1$. A previous lawsuit alleging that the health troubles of a family's cattle herd were due to DuPont's discharges of C-8 was settled under confidential circumstances. See Hall, Iles \& Morello-Frosch, supra note 1, at 20. 
sue, and the local population did not have sufficient information or resources to generate this costly evidence. ${ }^{4}$

In most courts these days, such a lawsuit would get tossed. But surprisingly, after making a series of tentative findings related to the presence of C-8 in the water supply and DuPont's increasing internal questioning about C-8's toxicity (revealed after limited disclosure), a state district court certified the group of nearby residents as a class under Rules 23(b)(1)(A) and 23(b)(2) of the West Virginia Rules of Civil Procedure. ${ }^{5}$ In particular, despite the fact that the group's members alleged different exposures and a variety of injuries, the court determined that there existed important common issues related to general causation, satisfying the key "commonality" requirement under Rule 23(b)(1)(A). ${ }^{6}$ Class certification prodded DuPont to agree to fund a $\$ 20$ million study about the effects of C-8 exposure, which ultimately linked exposure to six of the alleged diseases. ${ }^{7}$ This study provided a wealth of information, not only to the class members but also to society at large. In fact, the study has helped trigger subsequent actions by state and federal agencies to regulate $\mathrm{C}-8$ under their existing authorities. ${ }^{8}$

The underlying scenario-a population exposed to some unstudied substance ${ }^{9}$ - is all too common, but the resolution - the defendant funds a study to determine whether exposure to the substance caused plaintiffs' injuries - is rare. Without some scientific data substantiating a link between exposure to a substance and a specific harm, classes usually do not get certified and plaintiffs usually cannot survive summary judgment. On the one hand, this makes sense. Litigation, like regulation, should be based on reliable scientific evidence in order to allocate societal resources toward mitigating real risks. On the other hand, the typical outcome exacerbates a problem with risk-manage-

4. See generally In re E. I. Du Pont, 2016 WL 659112.

5. Leach, 2002 WL 1270121, at *18. West Virginia's Rule 23 is identical to the federal Rule 23. Compare W. VA. R. Civ. P. 23, with Fed. R. Civ. P. 23.

6. Leach v. E.I. Du Pont de Nemours \& Co., No. 01-C-608, 2002 WL 1270121, at *10 (W. Va. Cir. Ct. Apr. 10, 2002). The group also satisfied the "numerosity" and "typicality" requirements. Id. at $* 9, * 11$.

7. In re E. I. Du Pont De Nemours \& Co. C-8 Pers. Injury Litig., No. 2:13-CV-170, 2016 WL 659112, at $* 2$ (S.D. Ohio Feb. 17, 2016).

8. See e.g., Amena H. Saiyid, EPA to List Nonstick Toxics as Hazardous Substances This Year, BLOOMBERG ENv'T (Apr. 9, 2019, 12:04 PM), https://news.bloombergenvironment.com/environment-and-energy/epa-to-list-nonstick-toxics-as-hazardous-substances-this-year-1. See generally McGarity, supra note 1, at 1038-49 (describing cooperation between agencies in light of the DuPont litigation).

9. This Article focuses on the toxic tort context, but some of the concerns raised might be mirrored in other contexts such as the products liability context. 
ment schemes in the United States: Both litigation and regulation require scientific data in order to effectively manage risk, but there exist insufficient incentives to generate this costly evidence.

Toxic tort claims are expensive and difficult to litigate, even when plaintiffs allege harms from well-documented toxic substances that cause signature diseases. ${ }^{10}$ The long average latency periods for various known disease-causing substances-for example, twenty-five years for arsenic and eighteen years for asbestos ${ }^{11}$-frustrate efforts to link any injury to the defendant's past conduct. ${ }^{12}$ And, of course, there is the risk that, by the time plaintiffs manifest their injuries, the defendant may be insolvent, difficult to find, or long out of business. ${ }^{13}$

Without existing scientific evidence that establishes a link between a substance and some harm, plaintiffs are generally unable to bring successful claims. To succeed on a toxic tort claim, for example, courts typically require plaintiffs to establish both general and specific causation. ${ }^{14}$ General causation focuses on whether a substance is capable of causing plaintiffs' injuries ${ }^{15}$ and often requires plaintiffs to present epidemiological evidence demonstrating the link. ${ }^{16}$ Once plaintiffs prove general causation, they must prove that their specific injuries were caused by the defendant's conduct in exposing them to the substance. When no epidemiological data on the effects of a substance exists, a few courts might allow plaintiffs to generate data on general and spe-

10. One common example is the link between exposure to asbestos and mesothelioma. See Hall, Iles \& Morello-Frosch, supra note 1, at 16.

11. Allan T. Slagel, Note, Medical Surveillance Damages: A Solution to the Inadequate Compensation of Toxic Tort Victims, 63 IND. L. J. 849, 852 n.15 (1988).

12. See e.g., Arvin Maskin, Konrad L. Cailteux \& Joanne M. McLaren, Medical Monitoring: A Viable Remedy for Deserving Plaintiffs or Tort Law's Most Expensive Consolation Prize?, 27 WM. Mitchell L. Rev. 521, 526-27 (2000) ("[T]he longer the latency period, the more likely that plaintiffs will have exercised other lifestyle or occupational choices that arguably could have contributed to their illness, rendering a verdict against the defendants less likely.").

13. There is a large literature comparing the relative effectiveness of litigation versus regulation. Compare Peter Menell, The Limitations of Legal Institutions for Addressing Environmental Risks, 5 J. Econ. Persp. 93, 93-94 (1991) (discussing the limits of tort litigation in the environmental context), with Henry N. Butler, A Defense of Common Law Environmentalism: The Discovery of Better Environmental Policy, 58 CASE W. REs. L. REv. 705, 737-39 (2008) (describing the ways that the common law can lead to more efficient environmental policy by providing more opportunities to adjust to changes in technology, societal preferences, and experiential learning).

14. Plaintiffs usually bear the burden of proof on causation for most causes of action under the common law.

15. Michael D. Green, D. Mical Freedman \& Leon Gordis, Reference Guide on Epidemiology, in Reference Manual on Scientific Evidence 333, 392 (Fed. Jud. Ctr., 2d ed. 2000).

16. Michael Dore, 3 Law of Toxic Torts $\$ 28: 34$ (2019) (discussing the trend away from admitting evidence relying only on data from animal bioassays). 
cific causation through the adversarial process. ${ }^{17}$ But even if courts allow it, the adversarial process is an inapt way of developing and establishing new scientific evidence and conclusions. ${ }^{18}$ Meanwhile, reliable epidemiological analysis typically costs millions. ${ }^{19}$ Potential plaintiffs would face significant incentives to free ride on others' expenditures in generating this evidence; once generated, anyone can use such evidence in future litigation or regulation. ${ }^{20}$

In most of these cases, plaintiffs would also be unable to recover for diagnostic tests and other health monitoring for latent injuries. Although courts in many states have recognized claims or remedies for medical monitoring under some circumstances, ${ }^{21}$ these courts typically require plaintiffs to present substantial scientific information, too. A plaintiff must demonstrate, among other things, that it is more likely than not that the plaintiff will develop a disease and that monitoring could lead to an improved outcome through early detection and treatment. ${ }^{22}$ In other words, there must exist not only significant scientific knowledge about the link between exposure to a substance and a future harm, but also medical advancements in the treatment of that harm. The rationale for blocking claims without this evidence is again reasonable: Courts fear a flood of frivolous lawsuits that can waste

17. Some courts, for example, have allowed dueling experts to testify on general causation when no epidemiological evidence exists. See J.C. McElveen, How is Epidemiologic Evidence Admitted as Proof of Causation?, in 2 Toxic Torts Prac. Guide $§ 16: 7$ (Karen A. Gottlieb ed., 2018). See also Wendy Wagner, When All Else Fails: Regulating Risky Products Through Tort Litigation, 95 GEO. L.J. 693, 700 (2007).

18. See discussion infra Part II. For recent concerns about this, see Sara Randazzo, In Roundup Case, the Science Will Go on Trial First, Wall ST. J. (Feb. 15, 2019, 10:58 AM), https:// www.wsj.com/articles/in-roundup-case-the-science-will-go-on-trial-first-11550246311.

19. In the DuPont case, the parties agreed to independent epidemiological analysis paid for by the defendant, which cost $\$ 20$ million. See In re E. I. Du Pont De Nemours \& Co. C-8 Pers. Injury Litig., No. 2:13-CV-170, 2016 WL 659112, at *2 (S.D. Ohio Feb. 17, 2016).

20. The epidemiological data that supports toxic tort litigation can be thought of as a public good.

21. In 2005, thirteen states and the District of Columbia recognized medical monitoring absent a present physical injury, while sixteen states explicitly rejected a claim for medical monitoring, four states had not articulated a test, and eighteen states had not been faced with the question. D. Scott Aberson, Note, A Fifty-State Survey of Medical Monitoring and the Approach the Minnesota Supreme Court Should Take When Confronted with the Issue, 32 WM. MitcheLL L. REv. 1095, 1114-15 (2006). Since 2005, a few more states have weighed in on the availability of this claim. When allowed, such a claim or remedy usually provides for a court-administered fund that pays out expenses for diagnostic tests and other health monitoring. See Logan Glasenapp, Judicially Sanctioned Environmental Injustice: Making the Case for Medical Monitoring, 49 N.M. L. REv. 59, 74-75 (2019).

22. See, e.g., Potter v. Firestone Tire \& Rubber Co., 863 P.2d 795, 816 (Cal. 1993); Exxon Mobil Corp. v. Albright, 71 A.3d 30, 81-82 (Md. 2013); Hansen v. Mountain Fuel Supply Co., 858 P.2d 970, 976 (Utah 1993). 
valuable judicial and defendant resources, which could otherwise be used to compensate presently injured plaintiffs. ${ }^{23}$

Currently, there are thousands of substances for which we do not have sufficient data regarding their effects on human populations. ${ }^{24}$ Under the Toxic Substances Control Act (TSCA) - the federal statute governing substances used in industrial processes-the Environmental Protection Agency (EPA) can act to restrict substances only if it proves that the substances present an unreasonable risk of harm. ${ }^{25}$ This is consistent with the reality that regulation, if it is to be welfareenhancing, requires significant amounts of information. ${ }^{26}$ Otherwise, the regulation would likely do more harm than good. The EPA generally does not require firms to provide toxicological data for any substances used in their industrial processes. ${ }^{27}$ There is widespread agreement that the pace of research on unstudied substances is too slow; this was one of Congress's motivations in passing an amendment to the TSCA in 2016.

This Article highlights the problem of insufficient and persistently lagging epidemiological data or other reliable scientific information on potential harms from exposure to substances. The difficulties plaintiffs face in recovering for harms ex post means that firms face insufficient pressure to evaluate and then mitigate the risk of harms ex ante. The lack of information also makes it impossible for regulators to efficiently manage harms ex ante. The result is that firms might overuse potentially harmful substances and reduce social welfare. In these cases, the value of generating this information is highest particularly

23. This is not an abstract fear. In one of the cases motivating the hypothetical, the analysis cost $\$ 12$ million, and the defendant went bankrupt as a result. See Sara Jerving, Report: Tainted Soil Near Tonawanda Coke, Investigative Post (Jan. 16, 2019), http://www.investigativepost .org/2019/01/16/report-tainted-soil-near-tonawanda-coke/; Daniel Telvock, Tonawanda Coke Files for Chapter 11 Bankruptcy, WIVB.com (Oct. 16, 2018, 5:54 PM), https://www.wivb.com/ news/local-news/tonawanda-coke-files-for-chapter-11-bankruptcy/1528121691.

24. For example, there are more than 80,000 substances on the Toxic Substances Control Act's inventory for which there is no reliable information on harms. See U.S. Gov'T AcCOUNTABILITY Off., GAO-06-1032T, Chemical Regulation: Actions are Needed to Improve the Effectiveness of EPA's Chemical Review Program 1 (2006).

25. 15 U.S.C.A. $\$ 2605$ (a) (West 2016) ("If the Administrator determines . . that the manufacture, processing, distribution in commerce, use, or disposal of a chemical substance or mixture, or that any combination of such activities, presents an unreasonable risk of injury to health or the environment, the Administrator shall by rule . . . apply one or more of the following requirements to such substance or mixture to the extent necessary so that the chemical substance or mixture no longer presents such risk ....").

26. Interestingly, DuPont argued that any tort litigation should wait until "State administrative agencies" resolved the issue of general causation. See Leach v. E.I. Du Pont de Nemours \& Co., No. 01-C-608, 2002 WL 1270121, at *10 (W. Va. Cir. Ct. Apr. 10, 2002).

27. The requirement is triggered when the company has reason to believe a substance is harmful. See 15 U.S.C.A. § 2607(e) (West 2016). 
because no current data exists. Any monitoring or analysis could benefit others by providing valuable new information-positive or negative-about the risks of the substance at issue.

In Part I, this Article describes why this data gap exists. It also explains why such data is important for creating incentives for optimal environmental health and safety, whether these incentives emerge privately through contracts or tort litigation or publicly through regulatory law. ${ }^{28}$ The Article then explores potential solutions to this persistent data gap. In Part II, the Article offers ways that tort law can address the data gap, drawing inspiration from a few distinctive cases. In particular, it proposes a new tort cause of action that, if clearly defined and adequately limited, could play a role in systematically generating this information. In Part III, the Article offers two regulatory options for addressing the data gap.

As long as humans continue to innovate, new substances will emerge. Optimal standards of care are not static; they change over time based on new information of risks. ${ }^{29}$ Robust and reliable data on the risks of these substances, especially when potential harms may be latent, is expected to lag. But the tolerance for expected lags obscures the fact that there are persistent barriers to the production of such data. Standards of care will not become optimal over time if there are insufficient incentives to measure and evaluate the effects of new and old substances. This Article describes this persistent data gap, highlights its importance, and explores ways to make sure that incentives for generating this data are present.

\section{A Persistent Data Gap}

Our risk-management system relies on information about risks of new products or processes emerging over time. But when harms are latent, it is expensive and difficult to make these causal links. This Part

28. The Article focuses on optimal deterrence and risk mitigation because, I argue, the persistent data gap must be solved in order for tort law to fulfill this objective. The data gap does not need to be solved in order for tort or regulatory law to achieve other objectives, such as compensation for victims.

29. See Surajeet Chakravarty, David Kelsey \& Joshua C. Teitelbaum, Tort Liability and Unawareness, Geo. L. Fac. Publications \& Other Works 2067, 19-25 (2019), https://scholarship.law.georgetown.edu/facpub/2067/ (describing and modeling how a negligence liability rule in tort litigation spreads awareness of new information about what due care requires); see also Alfred Endres \& Regina Bertram, The Development of Care Technology under Liability Law, 26 Int'L Rev. L. \& Econ. 503, 503-18 (2006); Claus Ott \& Hans-Bernd Schäfer, Negligence as Untaken Precaution, Limited Information and Efficient Standard Formation in the Civil Liability System, 17 InT'L ReV. L. \& ECON. 15, 15 (1997). 
discusses the resulting persistent data gap that litigation and regulation do not systematically address.

\section{A. System Assumptions}

Under the economic perspective, well-functioning free markets allocate scarce resources efficiently and maximize aggregate welfare. ${ }^{30}$ But at times, the market fails to do so, such as when it fails to account for unpriced effects on third parties, referred to as externalities. The idea is that if the market accounted for these effects, the welfare-maximizing equilibrium outcome would actually have been higher (positive externalities) or lower (negative externalities). While in some contexts, decentralized bargaining between parties can ensure that all such effects are internalized, ${ }^{31}$ these solutions are least likely in the environmental context where there are often multiple victims of exposures. ${ }^{32}$

In these scenarios, we rely on tort litigation and regulation to efficiently manage risks. ${ }^{33}$ Tort litigation offers coordination mechanisms to reduce transaction costs, allowing plaintiffs to confront relevant defendants and get defendants to pay for revealed harms ex post. This should force firms to internalize those harms and act in a socially optimal way in the first instance. ${ }^{34}$ Alternatively, regulators could force firms to internalize expected harms through ex ante regulation by setting standards at socially optimal levels. Both systems have their advantages and their disadvantages in the environmental context. ${ }^{35}$

30. See generally Vilfredo Pareto, Cours d’économie politique (1896).

31. Ronald H. Coase, The Problem of Social Cost, 3 J.L. \& Econ. 1, 19 (1960).

32. See Menell, supra note 13, at 102-05 (describing various reasons environmental harms are not likely to be adequately deterred outside of regulation). One reason transaction costs are high in the environmental context is because there are often multiple potential victims of environmental harms. Another reason, the focus of this Article, is that the key information on causation is sometimes unavailable and costly to discover.

33. See, e.g., Steven Shavell, Liability for Harm Versus Regulation of Safety, 13 J. LEGAL STUD. 357, 368-71 (providing guidance for when regulation is more likely to provide for efficient risk-management as compared to tort litigation); Richard A. Epstein, Federal Preemption, and Federal Common Law, in Nuisance Cases, 102 Nw. U.L. Rev. 551, 557-58 (2008) (arguing generally that the need for regulation arises where transaction costs prevent adequate enforcement through private nuisance actions).

34. See Shavell, supra note 33, at 366-68.

35. Id. The two ways of dealing with the negative environmental externality would be equivalent, assuming that both estimate the same harms accurately. But compare Menell, supra note 13, at 93 (discussing the ways tort litigation might systematically undervalue environmental harms), with Butler, supra note 13, at 737-39 (describing how tort litigation can be more efficient by providing opportunities to adjust to changes in technology, societal preferences, and experiential learning). 
In this Article, I focus on one specific problem that often arises in this context: The problem of substantiating latent harms. In particular, an innovative product or process might - or might not - have unintended harmful effects that are revealed much later. Because the product or process is new, there is little information about potential negative effects at its introduction. Do we wait some predetermined time period to evaluate potential latent harms? Or do we learn about them as we go?

Generally speaking, there are two ways to deal with new products and processes and their unknown, possibly latent risks: Prohibit the use of products and processes until they are proven safe or allow their use and learn about the risks over time. The first option is embodied in the precautionary principle, which states that those wanting to take an action bear the burden of proving that the action does not create a risk of harm to the public or the environment. ${ }^{36}$ Many European countries have adopted the precautionary principle as a core riskmanagement strategy under some circumstances, ${ }^{37}$ and the European Union has initiated programs to limit the availability of unstudied substances. ${ }^{38}$ In theory, this principle protects humans and the environment from the potential effects of such substances; it generally bars their use unless proponents generate exonerating scientific evidence.

But following such a precautionary principle delays the introduction of new and innovative products and processes, and such delays can have negative consequences on human health and the environment. ${ }^{39}$ In his article criticizing a strong version of the precautionary principle, Professor Cass Sunstein brings up the familiar example of "drug lag," the lag that results from delaying the introduction of new medicines and drugs into the market. ${ }^{40}$ Sunstein warns, "If a government takes [a

36. The precautionary principle "allows the competent public authority to take, on a provisional basis, preventive protective measures on what is as yet an incomplete scientific basis, pending the availability of additional scientific evidence." Case T-13/99, Pfizer Animal Health SA v. Council, 2002 E.C.R. II-03305, II 387.

37. See, e.g., Communication from the Commission on the Precautionary Principle, at 7-8 COM (2000) 1 final (Feb. 2, 2000) (recognizing "where there are indications that the possible effects on the environment or human, animal or plant health may be potentially dangerous and inconsistent with the chosen level of protection" and when at the same time the available data precludes a detailed risk evaluation).

38. See Registration, Evaluation, Authorisation and Restriction of Chemicals (REACH), (EC) No 1907/2006 as of 30 Dec. 2006, O.J. (L 396) (placing the burden of proof on firms to identify and manage the risks linked to the substances they manufacture and market in the European Union).

39. See, e.g., Cass R. Sunstein, Beyond the Precautionary Principle, 151 U. PA. L. Rev. 1003, 1003 (2003) (arguing that the precautionary principle is actually paralyzing because all actions, including inaction, create a risk to health or the environment).

40. Id. at 1023 . 
precautionary] approach, it might protect people against harms from inadequately tested drugs; but it will also prevent people from receiving potential benefits from those very drugs." 41 It is easy to imagine similar concerns in the standard environmental context. While exposures to unstudied substances may prove harmful, this possibility must be weighed against the benefits of using the new substances, among other things.

For this reason, the United States generally adopts the other option: We allow new products and processes until there is evidence that they should be regulated. ${ }^{42}$ This approach recognizes that it is impossible to analyze the tradeoffs and opportunity costs of prohibiting these innovations without more information. By allowing them, we reap the immediate benefits of the innovations-be they cheaper, faster, or otherwise better for consumers. And by observing the use of these innovations over time, we gather information about risks. ${ }^{43}$

The idea is that the interaction of tort, contract, and regulatory systems will address any important externalities as information on new risks emerges over time as the innovative product or process is increasingly used. Tort litigation, in particular, has been regarded as having an advantage over regulation in this regard. Scholars have argued that tort litigation provides a form of data collection about risks that otherwise might not be evident at first, allowing standards to adjust over time. ${ }^{44}$

Or at least that is the theory. In practice, however, tort litigation and regulation require threshold levels of scientific information on causation to warrant action. But information on latent harms does not emerge organically the way that information on immediate harms might emerge over time. Scientific information on latent harms is expensive to generate, requiring thoughtful and targeted investigation and analysis. The next Section discusses these challenges.

\section{B. Practical Challenges}

In order to generate reliable data on whether an exposure to a substance contributes to a particular harm, researchers need substantial amounts of information on large groups of people over time. Analyzing the medical history or ordering the medical monitoring of one in-

41. Id.

42. See, e.g., Toxic Substances Control Act, 15 U.S.C.A. § 2607(e) (West 2016) (no testing requirements until threshold findings of harm).

43. This approach is reflected in Toxic Substances Control Act, discussed infra Part I.C.

44. See, e.g., Robert L. Rabin, Reassessing Regulatory Compliance, 88 GEO. L.J. 2049, 2068-70 (2000); Butler, supra note 13, at 737-39. 
dividual is unlikely to generate useful information about general or specific causation in such cases. Researchers must identify the exposed population, collect biological and other information about the extent of the exposure on a large enough sample of the population, collect similar information for a control group, and tie the exposure to outcomes. And they need to study large enough groups of people in order to make it possible to find statistically significant results given the baseline levels of risk and harm incidence and any confounding factors. Collecting and analyzing such data is expensive, time-consuming, and difficult in most cases, but particularly so when harms are latent.

When harm caused by a substance manifests itself immediately, it is easier to collect and analyze data corroborating the link. Consider the risk of dying on the job. The population of employees exposed to the risk is well-defined within the particular industry, and employers have long been required to report such fatalities to government agencies. ${ }^{45}$ This generates data that makes it possible to calculate detailed risks for different occupations within an industry. ${ }^{46}$ And even without such data, on-the-job fatalities tend to be visible, and workers are generally aware of these risks. ${ }^{47}$ Because risk perceptions are more reliable, employees can make informed choices about occupations and exposures. ${ }^{48}$

But when harms are latent, such as with most environmental harms, it is much more difficult to collect and analyze data relevant to calculating risks. ${ }^{49}$ For one, the relevant exposed population might not be easy to identify. People might move or switch jobs, and firms might switch products or processes before harm manifests. The exposure might occur in nonobvious ways or the harm might manifest itself differently in individuals. In addition, researchers must be able to control for potentially contributing factors, such as lifestyle and environment. The population might be exposed to other risks during the time it takes for harm to manifest itself, or the baseline incidence of harm might be high over such long periods of time. Or, the population

45. See Bureau of Lab. Stat., Census of Fatal Occupational Injuries, https://www.bls.gov/iif/ oshcfoi1.htm (last visited June 23, 2019).

46. Id.

47. See W. Kip Viscusi, Pricing Lives: Guideposts for a SAfer Society 13-15 (2018) (summarizing research on economic and policy endeavors to establish a value of a statistical life).

48. Id.

49. See Jean Macchiaroli Eggen, It's About Time: The Long Overdue Demise of Statutes of Repose in Latent Toxic Tort Litigation, 68 CASE W. Res. L. Rev. 23, 36-49 (2017) (describing some of these challenges in more detail). 
might have underlying conditions or proclivities for which researchers would need to control. In the case of some environmental exposures, for example, the nearby population might be predominantly low-income or share some other characteristic. ${ }^{50}$ Large sample sizes allow researchers to control for many confounding factors. Of course, collecting extensive medical, biological, and physical information on such large groups of exposed and nonexposed individuals over time is expensive, time-consuming, and difficult. ${ }^{51}$

It is no surprise, then, that these studies typically cost millions of dollars. It cost DuPont, for example, $\$ 20$ million for the study examining the link between C-8 exposure and various harms. In that case, the parties agreed to have three independent epidemiologists ${ }^{52}$ form a "Science Panel" that would examine blood samples and medical histories from approximately 69,000 individuals exposed to drinking water contaminated with C-8.53 The parties agreed that the Science Panel would issue findings - either a "Probable Link Finding" or a "No Probable Link Finding"- for each disease the Panel studied. ${ }^{54}$ In the end, the Science Panel issued a Probable Link Finding for six diseases-kidney cancer, testicular cancer, thyroid disease, ulcerative colitis, high cholesterol, and pregnancy-induced hypertension and preeclampsia-and it delivered No Probable Link Findings for the rest of the alleged diseases. ${ }^{55}$ Although sampling and analysis technology is advancing rapidly, making studies more efficient, the cost of epidemiological studies is likely to remain significant for the foreseeable future. ${ }^{56}$ And, unlike in DuPont's case, defendants rarely fund

50. These types of concerns are also prevalent when analyzing the risks of pharmaceutical drugs. In those cases, the population might have devastating or even terminal preconditions.

51. This is particularly true about the data collection component for both the researchers and the participants. I have participated in these kinds of long-term epidemiological studies with multiple follow-up data collection and interviews. In the last update for one of these studies, for example, I was required to provide a blood and urine sample, perform various tasks, and participate in a long, in-person interview. The update took more than five hours.

52. In re E. I. Du Pont De Nemours \& Co. C-8 Pers. Injury Litig., No. 2:13-CV-170, 2016 WL 659112, at $* 2$ (S.D. Ohio Feb. 17, 2016). The parties mutually agreed to select the following experts: Tony Fletcher, Ph.D. of the London School of Hygiene and Tropical Medicine, David Savitz, Ph.D., M.S., of Brown University, and Kyle Steenland, Ph.D., Ph.D., M.S. of Emory University. Id.

53. Id.

54. Id. at *1. Importantly, in addition to paying for the study, DuPont agreed not to contest general causation in future actions that alleged an injury with a "Probable Link Finding." Id. at *3. It retained the right, however, to contest specific causation among other things. Id.

55. Id. at $* 3$.

56. See Donald B. Myers Jr. \& Paul A. Locke, Modernizing U.S. Chemicals Laws: How the Application of Twenty-First Century Toxicology Can Help Drive Legal Reform, 20 N.Y.U. EnVTL. L.J. 35, 39 (2012) (documenting increasing efficiency); Warren Strauss et al., Improving 
epidemiological studies during litigation when there exists no reliable evidence on causation.

\section{Tort and Regulatory Limitations}

The ability of tort litigation and regulation to effectively manage potential latent harms from innovative products and processes is limited by the difficulties in generating important information on causation. This is true even for tort liability, which ordinarily has a significant advantage over regulation in bringing to light information on risks over time.

As an initial matter, it is true that juries have sometimes imposed liability on defendants for new products or processes based on weak (or nonexistent) scientific evidence on causation. For example, after a prominent tort case in which the plaintiff alleged latent harms from her silicone breast implants, two jurors indicated after the decision that they did not think that silicone caused the plaintiff's disease. ${ }^{57}$ Despite this, the jury awarded her $\$ 5.2$ million in compensation because she was sick, she needed the money, and there was no evidence that silicone was safe..$^{58}$ Litigation about the potential harms of Bendectin, a morning-sickness pill prescribed to pregnant women, and other drugs also resulted in large jury awards despite little information about causation. ${ }^{59}$ There are questions about whether current litigation on the effects of Roundup, a weed-killer produced by Monsanto, is justified based on the available scientific evidence. ${ }^{60}$

Cost-Effectiveness of Epidemiological Studies Via Designed Missingness Strategies, 29 STAT MED. 1377-87 (2010) (proposing one way to lower costs, though the case studies still cost millions).

57. See Joni Hersch, Breast Implants: Regulation, Litigation, and Science, in Regulation Through Litigation 142, 142 (W. Kip Viscusi ed., 2002). In fact, two courts relied on expert panels to evaluate the complex causal issues. See generally Laural L. Hooper, Joe S. Cecil \& Thomas E. Willging, Neutral Science Panels: Two Examples of Panels of Court-Appointed Experts in the Breast Implants Product Liability Litigation, Fed. Jud. CTr. (2000), https://www.fjc .gov/sites/default/files/2012/NeuSciPa.pdf.

58. See Hersch, supra note 57.

59. Jane E. Brody, Shadow of Doubt Wipes Out Bendectin, N.Y. Times (June 19, 1983), https:/ /www.nytimes.com/1983/06/19/weekinreview/shadow-of-doubt-wipes-out-bendectin.html.

60. See, e.g., Randazzo, supra note 18. Monsanto's actions in suppressing scientific information appeared to play a role in the litigation. In upholding punitive damages, California Superior Court Judge Winifred Smith found that "Monsanto made efforts to impede, discourage, or distort the underlying scientific inquiry." Amanda Bronstad, Judge Who Reduced \$2B Roundup Verdict Said Monsanto Manipulated the Science, LAw.com (July 26, 2019, 5:16 PM), https://www .law.com/therecorder/2019/07/26/judge-who-reduced-2b-roundup-verdict-said-monsanto-manipu lated-the-science/; see also Michael Hiltzik, Column: Did a Jury Ignore Science When It Hit Monsanto with a \$2-Billion Verdict?, L.A. Times (May 17, 2019 6:20 AM), https://www.latimes.com/ business/hiltzik/la-fi-hiltzik-monsanto-glyphosate-verdict-20190517-story.html. 
Some of these examples demonstrate how tort litigation can get things very wrong when it allows liability without sufficient evidence on causation. But tort law's mistakes are only evident because the large damage awards motivated subsequent research to get at the truth. For example, consider again the case of silicone breast implants. Only after numerous plaintiffs had won multimillion-dollar awards through tort litigation did the Food and Drug Administration (FDA) require implant manufacturers to provide information on the longterm safety of implants and initiate studies evaluating links between implants and adverse outcomes. ${ }^{61}$ Bendectin has also since been vindicated by multiple epidemiological studies, ${ }^{62}$ and a version of it has reentered the market. ${ }^{63}$ It remains to be seen whether Roundup, too, will be vindicated with additional research into its risks.

In this way, large and unpredictable tort awards can help generate evidence that will eventually move us closer to the socially optimal activity and risk level for innovative products and processes. But this data generation that emerges through tort law's mistakes is inconsistent and costly. For example, in the case of Bendectin, the lawsuits caused the pill to be pulled from the market, which was costly not only to the manufacturer but also to society as well; scholars have found adverse consequences on pregnant woman, such as increased nausearelated hospitalizations. ${ }^{64}$ There have also been claims that the lawsuits made drug firms wary of offering drugs aimed at pregnant women in general given the higher probability of large damages despite weak evidence of causation. ${ }^{65}$

Thus, unwarranted damage awards have unintended negative consequences (over-deterring the introduction of innovative products and processes and normalizing unsupported findings on causation by courts), but they also have unintended positive consequences (motivating data generation on causation). The negative consequences have received more attention, spurring tort reforms. Importantly, courts

61. Hersch, supra note 57.

62. See, e.g., PM McKeigue et al., Bendectin and Birth Defects: I. A Meta-Analysis of the Epidemiologic Studies, 50 Teratology 27, 27 (1994); Robert L. Brent, Bendectin: Review of the Medical Literature of a Comprehensively Studied Human Nonteratogen and the Most Prevalent Tortogen-Litigen, 9 Reprod. Toxicology 337, 337 (1995).

63. Its new trademark name is Diclegis. See Robert Lowes, FDA Approves Diclegis as First Morning Sickness Drug in 30 Years, Medscape Med. News (Apr. 9, 2013), https://www.med scape.com/viewarticle/782212.

64. See, e.g., Jeffrey S. Kutcher et al., Bendectin and Birth Defects II: Ecological Analyses, 67 Birth Defects Res. 88 (2003).

65. D.A. Wing, B. Powers \& D. Hickok, U.S. Food and Drug Administration Drug Approval: Slow Advances in Obstetric Care in the United States, 115 Obstetrics \& Gynecology 825, 825-33 (2010). 
have tried to limit such unwarranted damages going forward by adopting less permissive approaches to the kinds of expert testimony that would support causation. At the same time, courts also started employing more stringent controls on class certification.

In federal courts, for example, the famous case Daubert v. Merrell Dow Pharmaceuticals set a new, more demanding standard for admitting expert testimony. ${ }^{66}$ Judges were to be gatekeepers, assessing "whether the reasoning or methodology underlying the testimony is scientifically valid and of whether that reasoning or methodology properly can be applied to the facts in issue." 67 Other jurisdictions have followed suit in adopting this standard. ${ }^{68}$ The effect of the Daubert standard was almost immediate; soon after its adoption, Professor David Bernstein observed that "most federal courts are interpreting Daubert as giving them wide authority to restrict the scope of admissible scientific evidence in toxic tort litigation and are using that authority aggressively." 69 Even when a case is allowed to go to a jury, courts are more willing to reduce large awards when they determine that insufficient reliable evidence had been presented during the proceedings. ${ }^{70}$

Similarly, Congress enacted the Class Action Fairness Act of 2005 $(\mathrm{CAFA})^{71}$ to combat perceived abuses by plaintiffs' attorneys in

66. 509 U.S. 579 (1993).

67. Id. at $592-93$.

68. See generally John M. Conley \& Scott W. Gaylord, Scientific Evidence in the State Courts: Daubert and the Problem of Outcomes, 44 Judges' J. 6, 7 (2005) (discussing several states' adoption or adaptation of Daubert and listing cases that demonstrate each state's approach to scientific evidence).

69. David E. Bernstein, The Admissibility of Scientific Evidence After Daubert v. Merrell Dow Pharmaceuticals, Inc., 15 CARDOzo L. REv. 2139, 2139 (1994); see also Kevin Hannon, Representing Plaintiffs in Toxic Tort Litigation, 26 CoLo. LAw. 56 (1997) (arguing that Daubert created a second burden of proof for plaintiffs, making cases more expensive); Anthony Z. Roisman, Martha L. Judy \& Daniel Stein, Preserving Justice: Defending Toxic Tort Litigation, 15 FORDham EnvtL. L. Rev. 191, 204 (2004) (arguing that judges acting as "gatekeeper[s]" often resulted in plaintiffs being unable to use scientific evidence on which they could previously rely); Craig T. Smith, Peering into the Microscope: The Rise of Judicial Gatekeeping after Daubert and Its Effect on Federal Toxic Tort Litigation, 13 B.U. J. of SCI. \& TeCH. L. 218, 220 (2007) (finding that courts became more active in determining the admissibility of expert testimony and arguing for greater acceptability of probabilistic evidence on causation). That said, some have argued that Daubert made it easier for plaintiffs to allege novel theories of causation. See, e.g., Wendy S. Neal, General Electric Co. v. Joiner: The Future of Scientific Evidence in Toxic Tort Litigation, 67 U. Cin. L. Rev. 881, 901 (1998).

70. See, e.g., Ely v. Cabot Oil \& Gas Corp., No. 3:09-CV-2284, 2017 WL 1196510, at*1-2 (M.D. Pa. Mar. 31, 2017) (vacating a jury award of $\$ 4.24$ million for damages relating to fracking-related water contamination and ordering a new trial after determining that the evidence was insufficient to support that award).

71. Class Action Fairness Act of 2005, Pub. L. No. 109-2, 119 Stat. 4 (codified as amended in scattered sections of 28 U.S.C.). 
bringing class-action lawsuits in plaintiff-friendly state courts. This led to these lawsuits either being brought in or being removed to federal courts. ${ }^{72}$ Because many environmental exposures affect large groups of individuals, class certification was an important source of leverage for these plaintiffs. For example, in the DuPont case, class certification was the pivotal moment in the litigation that led DuPont to agree to fund the analysis on causation. ${ }^{73} \mathrm{~A}$ state district court had certified the group of thousands of nearby residents as a class under Rules 23(b)(1)(A) and 23(b)(2) despite the fact that the group's members alleged different exposures and a variety of injuries. ${ }^{74}$ At least in economic terms, DuPont faced a choice between continuing to litigate against the large class of plaintiffs alleging a variety of injuries in a plaintiff-friendly state court and funding a study that had the potential to (and did) drastically reduce the number and variation of eventual claims. And even though the Science Panel's findings would not bind non-class members, the reliable evidence on causation that it produced would be persuasive in any future litigation involving residents around its other plants.

That kind of leverage-the certified class action-is now much harder to come by due to CAFA. DuPont, for example, used CAFA to remove future lawsuits pertaining to C-8 exposure to federal courts..$^{75}$ And federal courts were not open to certifying the diverse plaintiffs' classes, especially when the plaintiffs presented claims for medical monitoring, leading to the abandonment of these claims. ${ }^{76}$ One federal court, for example, refused to certify a class in the DuPont litigation because it held that the plaintiffs failed to show on a class-wide basis that they each faced significant exposures to C-8 that significantly increased their risk of contracting a qualifying disease. ${ }^{77}$

72. For a more thorough history of how CAFA generally has led to the decay of state courts, see Diego A. Zambrano, Federal Expansion and the Decay of State Courts, 86. U. CHI. L. REv. 2101 (2019).

73. See Hall, Iles \& Morello-Frosch, supra note 1, at 21-22 (citing the rush of bad publicity and the particular forum, a plaintiff-friendly state court).

74. Leach v. E.I. Du Pont de Nemours \& Co., No. 01-C-608, 2002 WL 1270121, at*18 (W. Va. Cir. Ct. Apr. 10, 2002).

75. Id.; see Hall, Iles \& Morello-Frosch, supra note 1, at 21-22.

76. Leach, 2002 WL 1270121, at*18. Without class certification, the plaintiffs pursued lowervalue property claims, such as claims for trespass. See Hall, Iles \& Morello-Frosch, supra note 1, at $21-22$.

77. See Rhodes v. E.I. du Pont de Nemours \& Co., 253 F.R.D. 365, 367 (S.D. W. Va. 2008) ("The plaintiffs have presented compelling evidence that exposure to C-8 may be harmful to human health, and the evidence certainly justifies the concerns expressed by the plaintiffs in this case. . . The fact that a public health risk may exist is more than enough to raise concern in the community and call government agencies to action, but it does not show the common individual injuries needed to certify a class action."). 
Thus, tort litigation fails to systematically generate useful information on latent harms. At times, it allows juries to take shots in the dark, especially if there is evidence that the defendant contributed to the lack of available scientific information on harms. ${ }^{78}$ Whenever these shots in the dark result in large damage awards, tort litigation might motivate further research on causation. But this unpredictable approach to dealing with a lack of reliable scientific evidence produces huge social costs, limiting the availability of often beneficial products and processes and normalizing unsupported findings on causation by courts. Bad science in courts is unlikely to be the answer. A shift to requiring more reliable scientific evidence and a more consistent approach to the certification of class actions undoubtedly produces benefits. But the emerging approach produces unintended costs, too. In particular, it reduces the probability of damage awards in cases of exposures that are not well-studied, thereby reducing the subsequent generation of scientific evidence. In other words, there is less opportunity for tort litigation to generate a shock to the system and attract funding to scientific study of underlying causation.

The inability of tort litigation to systematically generate useful scientific information on latent harms would not be concerning if there were sufficient other incentives for generating this information. ${ }^{79}$ There is reason, however, to think that there are not.

As an initial matter, it might seem reasonable to expect plaintiffs to generate the required scientific data prior to litigation if such data is increasingly required. But there are at least three hurdles that plaintiffs face in doing so. First, the reliability of the information is greatest when a large number of potential victims (and control groups) can be evaluated or monitored. This presents a difficult and costly coordination problem. After litigation commences, plaintiffs could use vehicles such as class actions to help solve this coordination problem. But again, such certification is increasingly unlikely without existing scientific evidence. Second, plaintiffs will often not have sufficient knowledge about substances and exposures to generate reliable information on their own. In particular, without the defendant's cooperation, plaintiffs would lack critical information on type, intensity, and duration of exposure, and this information could help with accurately as-

78. See, e.g., Bronstad, supra note 60 (reporting that the trial judge upheld punitive damages in the Roundup case because "Monsanto made efforts to impede, discourage, or distort the underlying scientific inquiry").

79. See Epstein, supra note 33, at 557-58 (arguing that the need for regulation arises where transaction costs prevent adequate enforcement through private nuisance actions). 
sessing exposure and linking it to outcomes. ${ }^{80}$ And third, this information is costly to generate but, once generated, it can be used by any future plaintiffs and regulators. Scientific information on the existence or nonexistence of a link between exposure and outcomes is a pure public good: non-rivalrous and nonexcludable. For potential plaintiffs, then, there are strong incentives not to contribute to generating this information, especially because sometimes it will demonstrate that there is no link between exposure and alleged harms; it is rational to free ride on the information if it proves helpful after it has already been generated by someone else.

There is a growing industry that finances litigation..$^{81}$ This industry has enormous resources and could pay for studies if the expected return is sufficiently high. In such cases, a third-party funder could overcome the first hurdle, coordinating and paying for the expensive studies. But in order to maximize the reliability of the results, the funder would still have to obtain the necessary exposure information controlled by the defendant. And finally, the fact that this information can cut both ways and becomes publicly available further depresses the likelihood of initiating the studies based only on the benefits that accrue to the eventual plaintiffs (and their funders). Toxic tort cases are already expensive and difficult to prove.

Although information about the risks of new products and processes is often generated through scientific studies carried out by firms in the relevant industry, such studies are most likely to be conducted in response to potential tort or regulatory liability. Again, tort litigation is unlikely to systematically apply pressure for extensive epidemiological analysis.

Similarly, without key information on risk, regulation likely cannot be initiated either. ${ }^{82}$ TSCA recognizes that "adequate information should be developed with respect to the effect of chemical substances and mixtures on health and the environment," and it expresses the view "that the development of such information should be the responsibility of those who manufacture and those who process such chemical substances and mixtures." 83 But before the EPA is allowed to regulate industrial substances under TSCA, it must first find that the substances pose an "unreasonable risk of injury to health or to the

80. See Hersch, supra note 57 , at 142 .

81. See generally Deborah R. Hensler, Third-Party Financing of Class Action Litigation in the United States: Will the Sky Fall?, 63 DePAul L. Rev. 499 (2014) (discussing third-party financing and its potential expansion to class action litigation).

82. And, if initiated, it would be unlikely to improve social welfare given the significant risk of over or under regulation.

83. 15 U.S.C.A. § 2601(b)(1) (West 2016). 
environment." 84 This threshold finding must be supported by "substantial evidence," which would be difficult for the agency to prove absent reliable scientific information. ${ }^{85}$ In addition, regulation generally fails to provide incentives for creating this information. Again, although TSCA imposes some reporting requirements on manufacturers, those requirements have historically been triggered when information "reasonably supports the conclusion that" a substance "presents a substantial risk of injury to health." 86 Of the more than 80,000 substances on the TSCA inventory, the EPA has only required approximately 200 of these to be tested, producing very little data on potential health and environmental impacts. ${ }^{87}$ Accordingly, the EPA has used the TSCA to regulate the production of only five substances since its enactment. ${ }^{88}$ In 2016, Congress adopted the Frank R. Lautenberg Chemical Safety for the 21st Century Act, which amended TSCA to address some of its perceived failures. ${ }^{89}$ As relevant here, the amendment provides for additional authority for the EPA to require testing if it needs information for risk evaluation or other regulatory ends, ${ }^{90}$ but it is unclear whether and how the EPA will use this authority to combat the long list of unstudied substances. ${ }^{91}$

Like the limits on tort litigation, the limits on federal regulation make sense, too. For regulation to be welfare maximizing, regulators

84. 15 U.S.C.A. $\$ 2605$ (a) (West 2016) ("If the Administrator finds that there is a reasonable basis to conclude that the manufacture, processing, distribution in commerce, use, or disposal of a chemical substance or mixture, or that any combination of such activities, presents an unreasonable risk of injury to health or the environment, the Administrator shall by rule apply one or more of the following requirements to such substance or mixture to the extent necessary to protect adequately against such risk using the least burdensome requirements."). Previously, the agency also had to show that its proposed regulation was the "least burdensome" way to address the unreasonable risk. Congress has since removed this requirement, but it kept the requirement that the agency consider the costs and benefits of any regulation. See generally Frank R. Lautenberg Chemical Safety for the 21st Century Act, Pub. L. No. 114-182, 130 Stat. 448 (2016) (codified as amended at 15 U.S.C. $§ 2601$ ).

85. See Corrosion Proof Fittings v. EPA, 947 F.2d 1201, 1229-30 (5th Cir. 1991) (finding that the agency did not meet this standard when it sought to ban lead under TSCA).

86. 15 U.S.C.A. § 2607(e) (West 2016).

87. See U.S. Gov't Accountability Off., supra note 24.

88. Id. Congress passed The Lautenberg Act to urge EPA to go through substances more quickly, but the requirement of substantial evidence and cost-benefit analysis remains to ensure that EPA does not overreach.

89. See Frank R. Lautenberg Chemical Safety for the 21st Century Act, Pub. L. No. 114-182, 130 Stat. 448 (2016) (codified as amended at 15 U.S.C. $\$ 2601$ ).

90. Id. $\$ 4$.

91. For one thing, the Act specifically does not allow the EPA to use this additional authority "for the purposes of establishing or implementing a minimum information requirement of broader applicability." See id. 
need extensive information on the costs and benefits of regulating. ${ }^{92}$ The idea, then, is to focus on known and verifiable risks-and promote innovative products and processes quickly. ${ }^{93}$ Otherwise, regulation could be used too often, resulting in unintended consequences, such as the use of worse substitutes or less innovation..$^{94}$ This is sensible as long as information is generated by someone over time-allowing a regulatory agency to rationally update its regulations in light of new information. But if no one is monitoring and recording useful information on exposures and harms, then there cannot be efficient updating. ${ }^{95}$

Our system of insurance also plays a role in risk mitigation. ${ }^{96}$ Insurers could potentially monitor and produce relevant information on harms, but they too are unlikely to do so. Health insurers have incentives to lower risks and could deploy monitoring to potentially identify links that are geographically based. But insurers that cover potential victims are unlikely to have comprehensive coverage for all exposed victims and unlikely to coordinate with other insurers to figure out complex correlations. ${ }^{97}$ And moreover, the insurers will not have ac-

92. See, e.g., Al McGartland et al., Estimating the Health Benefits of Environmental Regulations: Changes Needed for Complete Benefits Assessment, 357 SCIENCE 457, 457-58 (2017) (describing how "health effects with less-certain evidence" or without a clear summary statement of the strength of the evidence are usually excluded from benefits analysis).

93. Some regulation might be more precautionary, but even then, the trigger is some threshold judgment about existing risks. Even in the European Union, where the precautionary principle is explicitly recognized, the principle has been accepted as a risk-management strategy to deal with cases "when there are reasonable grounds for concern that potential hazards may affect the environment or human, animal or plant health, and when at the same time the available data preclude a detailed risk evaluation." Communication from the Commission on the Precautionary Principle, at 8 COM (2000) 1 final (Feb. 2, 2000).

94. See e.g., Corrosion Proof Fittings v. EPA, 947 F.2d 1201, 1220-21 (5th Cir. 1991) (expressing concern that an outright ban in TSCA could lead to decreased innovation and no viable substitutes).

95. In other work, I have argued that a commitment to regulation justified by cost-benefit analysis should motivate research that could be used to rationally modify regulation if needed. See Caroline Cecot, Deregulatory Cost-Benefit Analysis and Regulatory Stability, 68 Duke L.J. 1593, 1617 (2019). This Article does a deep dive into whether current risk-management systems in fact provide sufficient incentives for generating this information.

96. Premiums are often tagged to regulatory compliance, and the insurer, seeking to minimize risk, monitors compliance with premium conditions and may help develop and implement riskmitigation schemes. See, e.g., Zurich Insurance Group, Corporate Responsibility HighLIGHTS 1, 14, 19-20 (2017). At least one empirical study has demonstrated how insurance, through risk-based pricing and monitoring, could improve environmental outcomes. See Haitao Yin, Howard Kunreuther \& Matthew W. White, Risk-Based Pricing and Risk-Reducing Effort: Does the Private Insurance Market Reduce Environmental Accidents?, 54 J. L. \& Econ. 325, 341-42 (2011).

97. Insurance would, however, provide compensation to victims. This is why I focus on using tort litigation primarily to address optimal deterrence and not compensation; insurance is a cheaper way of providing compensation. 
cess to relevant company information. Company liability insurers, meanwhile, would have no risk information on which to base their premiums in this context and no access to information on harms that could shed light on any links.

Advances in technology have made some tools of measuring, monitoring, and analyzing health data available to citizens, ${ }^{98}$ making it possible for them to play a role in producing valuable data about risks. There are concerns, however, about the quality of the information that untrained citizens would produce and whether such efforts would be sufficient. ${ }^{99}$ Recent research confirms that current citizen efforts have resulted in producing data of varying quality, especially when not supervised by independent researchers. ${ }^{100}$

Thus, we predominantly rely on independent researchers to produce this information with funding from governments and charitable funds. The information is unlikely to be systematically or comprehensively funded, generated, or analyzed. Researchers face pressures to focus on statistically significant results, which hinders the dissemination of useful information on non-harms and affects the choice of substances and populations to study. Such expensive studies are not undertaken at random, but they are chosen carefully based on some set of considerations. Researchers also face difficulties without substantial cooperation from both potential victims and alleged injurers. In addition to measuring exposures and understanding their pathways, researchers would need significant medical and geographical information. Of course, when researchers are able to do this, the information generated has been valuable. The epidemiological studies on the effects of fine particulate matter, ${ }^{101}$ exposure to the World Trade Center disaster, ${ }^{102}$ and extensive fracking, ${ }^{103}$ to name just a few, have gener-

98. George Wyeth et al., The Impact of Citizen Environmental Science in the United States, 49 ENVTL. L. ReP. 10237, 10237 (2019).

99. Id.

100. Id.

101. See Douglas W. Dockery et al., An Association Between Air Pollution and Mortality in Six U.S. Cities, 329 New Eng. J. Med. 1753 (1993). The study has helped monetize the benefits of reducing particulate matter, and these benefits constitute one of the largest categories of benefits of recent environmental regulations. See Office of Mgmt. \& Budget, Reports to Congress on the Costs and Benefits of Federal Regulations and Unfunded Mandates on State, Local, and Tribal Entities 6 (2007) (finding that the largest estimated benefit was from reduction in air pollution from fine particulate matter).

102. See, e.g., N.Y. Dep't of Health, World Trade Center (WTC) Health Studies and Information on Health Services (May 2017), https://www.health.ny.gov/environmental/investigations/ wtc/health_studies/responders.htm; World Trade Ctr. Health Programs, Research Projects, https://wwwn.cdc.gov/ResearchGateway/ResearchProjects (last visited June 23, 2019).

103. See, e.g., Johns Hopkins Bloomberg Sch. of Pub. Health, Study: Fracking Industry Wells Associated with Increased Risk of Asthma Attacks (July 18, 2016), https://www.jhsph.edu/ 
ated, and will continue to generate, useful information on underlying risks of products and processes that could be used in litigation and regulation. But relying solely on this option is inadequate. Insufficient funding for research is a concern, as demonstrated by the struggle for continued funding for long-term monitoring and health funds that have been established after large public disasters, such as the World Trade Center Registry and Health Program. ${ }^{104}$ The inadequacy of current research efforts is underscored by the sheer number of unstudied substances on the TSCA inventory.

In short, we generally allow innovative products and processes on the market, but we provide few incentives for testing them or monitoring their use over time. Neither potential plaintiffs, regulators, independent researchers, nor insurers are likely to systematically monitor and analyze the potential harms of new substances. In fact, as tort law reform has led to better scientific gatekeeping, incentives for generating data on harms have, in some cases, gone down; plaintiffs generally cannot overcome the significant hurdles to generating the data on their own, and there are less shock judgments that could motivate subsequent research by others. Independent research, with the limited funding that is available, cannot adequately fill this gap.

Reducing this persistent data gap is important. The effectiveness of current options for promoting socially optimal behavior hinges on the availability of reliable scientific data on latent harms. A persistent data gap results in enduring deviations from welfare-maximizing outcomes in the environmental context: Firms face inadequate incentives to study the effects of such substances beforehand and alter their behavior in order to mitigate potential risks. As has been noted in the context of corporate financial governance, "you manage what you measure." 105 There is a need for promoting systematic production of information about unknown harms from unstudied substances. ${ }^{106}$ This Article explores ways to promote the generation of this information through changes to common law and regulatory law.

news/news-releases/2016/study-fracking-industry-wells-associated-with-increased-risk-of-asthmaattacks.html.

104. See generally U.S. Gov't Accountability OfF., GAO-05-1020T, September 11: Monitoring of World Trade Center Health Effects Has Progressed, but Not for FedERAL RESPONDERS (2005).

105. Louis Lowenstein, Financial Transparency and Corporate Governance: You Manage What You Measure, 96 Colum. L. Rev. 1335, 1342-43 (1996).

106. Once the information is generated, current systems kick in to incentivize firms to internalize harms. 


\section{TORT WAYs Forward}

Because tort law traditionally played a beneficial role in providing data on unintended consequences of new products and processes, this Article first turns to the ways that tort law can play this role in the context of latent harms from environmental exposures without sacrificing its commitment to science-based results. I argue that insufficient scientific information on causation should not be a bar to some tort litigation; instead, tort litigation should adopt unique forms that can promote the development of this useful information.

The history of tort law is characterized by expanding forms of liability and types of remedies as knowledge, social norms, and expectations evolve over time. Recently, many courts have been open to causes of action or remedies for medical monitoring, ${ }^{107}$ and scholars have long argued for potential causes of action for the increased risk of future harms. ${ }^{108}$ Both developments have emerged at least in part as a response to the growing concern with exposures to substances that result in latent harms. ${ }^{109}$ But neither medical monitoring nor increased-risk claims get at the underlying concern in this Article. In particular, both require some threshold level of risk and, for the increased-risk claims, substantial knowledge of the likelihood, magnitude, and distribution of eventual harms. This Part focuses on ways tort could promote generation of data where none exists, such as by shifting the burden for causation and ordering informational monitoring in certain contexts.

\section{A. Burden-Shifting Approach to Causation}

One way that tort law could promote information generation is by shifting the burden for proving causation to the defendant after some showing by the plaintiff. ${ }^{110}$ Limited burden-shifting schemes can en-

107. E.g., Potter v. Firestone Tire \& Rubber Co., 863 P.2d 795, 816 (Cal. 1993); Exxon Mobil Corp. v. Albright, 71 A.3d 30, 81-82 (Md. 2013); Hansen v. Mountain Fuel Supply Co., 858 P.2d 970, 976 (Utah 1993). Consider also well-established expansions meant to address real, though intangible, harms, such as the early development of liability for assault and, more recently, bystander liability. E.g., Dillon v. Legg, 441 P.2d 912 (1968); I. de S. and Wife v. W. de S., At the Assizes, 1348 Year Book, Liber Assisarum, folio 99, placitum 60.

108. See, e.g., Kristen Chapin, Toxic Torts, Public Health Data, and the Evolving Common Law: Compensation for Increased Risk of Future Injury, 13 J. ENERGy Nat. Res. \& ENVTL. L. 129, 132 (1993).

109. E.g., Recent Cases, Supreme Judicial Court of Massachusetts Recognizes Cause of Action for Medical Monitoring of Tobacco Users, 123 HARv. L. REv. 1771, 1771 (2010) (arguing that relief in the form of medical monitoring has developed in response to "a world in which people regularly encounter environmental toxins, the effects of which are largely unknown").

110. A more radical option is to get rid of the requirement that a plaintiff prove general causation. But see Margaret A. Berger, Eliminating General Causation: Notes Towards A New 
sure that parties that are in the best position to acquire information are incentivized to do so. Sometimes such a burden-shifting requirement can come from state or federal law. For example, Pennsylvania law requires drilling operators to provide baseline test results of nearby water sources if they want to allege preexisting contamination in litigation. ${ }^{111}$ Operators that fail to test water prior to drilling would be presumptively liable for any contamination-thereby decreasing some of the difficulties plaintiffs have in proving causation. Title VII of the Civil Rights Act of 1964, the federal anti-discrimination statute, provides one of the most known versions of a burden-shifting framework in the context of demonstrating workplace racial discrimination. ${ }^{112}$ Once the plaintiff establishes a prima facie case of discrimination, the burden shifts to the defendant to articulate a nondiscriminatory reason for the adverse employment outcome. ${ }^{113}$

Occasionally, a burden-shifting requirement emerges in the common law. In Zuchowicz v. United States, ${ }^{114}$ for example, the issue was whether the excessive dosage of an admittedly risky pharmaceutical drug-for which even the permitted dose might be dangerouscaused the plaintiff's harm. Writing for the court, Judge Guido Calabresi held that under Connecticut law there was sufficient evidence of causation once the plaintiff showed that the drug could cause the harm and that the defendants administered an amount in excess of FDA and company guidelines. ${ }^{115} \mathrm{He}$ analogized the situation to cases in which a defendant's violation of some safety standard increased the probability of a harm to the plaintiff that in fact occurred. ${ }^{116}$ This was sufficient to show causation unless the negligent party demonstrated that there was some other cause. ${ }^{117}$

On the one hand, a burden-shifting scheme seems even more justified in the case of toxic torts, where plaintiffs are often exposed to potentially harmful substances without their knowledge or consent and without gaining any benefits to themselves. In this context, with

Theory of Justice and Toxic Torts, 97 Colum. L. REv. 2117, 2118-19 (1997) (arguing that while this option would allow plaintiffs to recover damages in many cases, it would not generate useful information and would not promote optimal deterrence).

111. Jon Hurdle, Science Panel Faults EPA Fracking Probe for Excluding Baseline Water Testing, StateImpact PA. (Jan. 13, 2016, 6:06 PM), https://stateimpact.npr.org/pennsylvania/2016/01/ 13/science-panel-faults-epa-fracking-probe-for-excluding-baseline-water-testing/.

112. 42 U.S.C.A. $§ 2000($ e) (West 2016).

113. McDonnell Douglas Corp. v. Green, 411 U.S. 792, 802 (1973).

114. 140 F.3d 381, 383 (2d Cir. 1998).

115. $I d$. at $390-92$. In this case, the plaintiff was generally made aware of the risks of the drug at the proper dosage.

116. Id. at 391.

117. Id. 
no scientific data on latent harms, the threshold inquiry would have to be the plaintiff's exposure to a significant amount of the substance. The defendant would then produce studies showing that the substance did not produce the plaintiff's harm or be held liable for the plaintiff's harm.

On the other hand, applying a burden-shifting framework when there is no scientific evidence on causation is a significantly more radical proposition than the burden-shifting framework the court applied in Zuchowicz. In that case, the court still required the plaintiff to make the threshold showing that the drug could cause the harm (whether the excess dose or not).118 This threshold showing-that the drug could cause the harm and did, in some way, cause the harm-was important to the court's analysis, and it limited the burden-shifting framework to the issue of whether the negligent, excess dose caused the plaintiff's harm as opposed to the allowable, non-negligent dose. In fact, the court explicitly distinguished the situation from the toxic tort context, where a long latency period could make it difficult for the plaintiff to establish general causation. ${ }^{119}$ Of course, the persistent lack of this kind of information in the toxic tort context is exactly the focus of this Article.

A complete, exposure-based burden-shifting approach would produce a variety of responses. Some firms might delay using innovative products and processes until they complete the required long-term testing on harms. This response would create significant delay, denying many users the benefits of the products and processes. Other firms might choose not to produce the data beforehand. They might instead choose to engage in monitoring, hoping that they acquire sufficient information to defeat causation by the time any litigation commences. Of course, this approach risks a costly damage award in the meantime.

118. Id. at 390-91 ("Where such a strong causal link exists, it is up to the negligent party to bring in evidence denying but for cause and suggesting that in the actual case the wrongful conduct had not been a substantial factor. . . It follows that when a negative side effect is demonstrated to be the result of a drug, and the drug was wrongly prescribed in an unapproved and excessive dosage (i.e. a strong causal link has been shown), the plaintiff who is injured has generally shown enough to permit the finder of fact to conclude that the excessive dosage was a substantial factor in producing the harm.").

119. The court recognized the additional difficulties in the toxic tort context, suggesting that the medical expert testimony about whether the drug could have caused the harm might be insufficient in more complicated contexts involving latent harms. See id. at 390 ("In this respect, we note that in the case before us, unlike many toxic torts situations, there was not a long latency period between the onset of symptoms and the patient's exposure to the drug that was alleged to have caused the illness. Rather, as Dr. Matthay testified, the plaintiff began exhibiting symptoms typical of drug-induced PPH shortly after she started taking the Danocrine. Under the circumstances, we cannot say that the fact finder was clearly erroneous in determining that, more probably than not, the Danocrine caused Mrs. Zuchowicz's illness."). 
But industry and academic researchers would have incentives to generate and analyze information on harms because juries would award plaintiffs compensation for their injuries.

This option might be better than allowing weak evidence to satisfy the plaintiff's burden of proving causation, but it might not be an improvement over the status quo that requires the plaintiff to provide reliable evidence on causation. It would be better than allowing plaintiffs to collect damages based on weak scientific evidence because at least under the burden-shifting framework, damages would be awarded on the recognition that there is, currently, insufficient evidence on harms. The cases would provide explicit incentives to generate reliable scientific information that, once generated, would stem further litigation. It is not much better than damages based on weak science, and possibly worse than the status quo prohibiting damages outright, because it would open the floodgates to litigation alleging a seemingly endless variety of harms in light of exposure, and it would be difficult for studies to rule out all potential allegations of harm. In the short term, many plaintiffs would get windfall damages. And, in all likelihood, many unstudied substances would eventually be proven to be relatively harmless.

One potential limit to the burden-shifting framework would be to provide a safe harbor when the defendant has put in place a monitoring system to evaluate any potential harms over time, as long as the defendant shares the results of its ongoing analysis. Courts would have to determine whether the system is sufficiently comprehensive to evaluate the kinds of harms alleged by the plaintiff. The effect of this more limited burden-shifting approach, which would only shift the burden on causation when a defendant has not undertaken any long-term analysis of potential harms to exposed populations, would be similar to the effect of the direct approach discussed in the next Section.

\section{B. Court-Ordered Informational Monitoring}

Another approach would be for courts to directly order the information monitoring and analysis required to evaluate the ongoing concerns about the safety of new products and processes as they are raised by litigants. In this Section, I consider two options for tort law to do so under some circumstances.

\section{Collateral Monitoring}

One option is to allow a court to order a defendant to fund informational monitoring as part of the damages for exposure-based causes of action, such as trespass. This option is analogous to the Tonawanda 
Coke Corporation case. ${ }^{120}$ For years, Tonawanda Coke produced coke, a coal-derived fuel, in its plant located in Tonawanda, New York. ${ }^{121}$ Concerned about the visible pollution emanating from the plant and a perceived high incidence of cancers, several community members began testing the air with handmade kits to understand the effect of the Tonawanda Coke's operations. ${ }^{122}$ These activities got the attention of the New York State Department of Environmental Conservation, which began its own study of air quality in the area around the plant. ${ }^{123}$ The agency's study revealed that the plant was emitting benzene, a known carcinogen regulated under the Clean Air Act, at levels more than seventy-five times higher than permitted. ${ }^{124}$ In the end, the EPA brought an enforcement action against Tonawanda Coke, and the company was found criminally liable for violating several provisions of the Clean Air Act and the Resource Conservation and Recovery Act. ${ }^{125}$ As part of its sentence, Tonawanda Coke was required to provide a specific kind of community service. ${ }^{126}$ It was required to fund two studies-a $\$ 711,000$ soil study and a $\$ 11.4$ million health study - that would help evaluate the effects of Tonawanda's environmental violations on the community. ${ }^{127}$ Researchers from the University of Buffalo were to lead the studies.

In this case, the district court determined that the harm suffered by the community included the uncertainty surrounding the increased risk of contracting future illnesses related to Tonawanda Coke's violations. The court related this harm to situations in which courts have recognized a reasonable threat of environmental harm as a cognizable

120. See United States v. Tonawanda Coke Corp., 5 F. Supp. 3d 343 (W.D.N.Y. 2014); Jerving, supra note 23 .

121. See U.S. EPA, Tonawanda Coke Corporation (TCC) Site, https://www.epa.gov/ny/tona wanda-coke-corporation-tcc-site (last visited April 2019).

122. Tonawanda, 5 F. Supp. 3d at 347.

123. Id.

124. Id.; Jerving, supra note 23. Martyn T. Smith, Advances in Understanding Benzene Health Effects and Susceptibility, 31 Ann. Rev. Pub. Health 133, 134-36 (2010) (describing evidence of benzene's role in increasing likelihood of cancers).

125. Tonawanda, 5 F. Supp. 3d at 351-52. The company's environmental control manager, Mark Kamholz, was sentenced to one year in prison. Id. at 352.

126. The federal sentencing guidelines allow the imposition of community service as a condition of probation "where such community service is reasonably designed to repair the harm caused by the offense." U.S. Sentencing Guidelines Manual § 8B1.3 (U.S. Sentencing CoMm'n 2018).

127. See United States v. Tonawanda Coke Corp., 5 F. Supp. 3d 343, 347 (W.D.N.Y. 2014) (requiring company to conduct evaluative projects recommended by community as condition of its probationary sentence for violating environmental requirements). The soil study has been completed, with some preliminary results. See Jerving, supra note 23. 
harm. ${ }^{128}$ Moreover, at least one of the key pollutants-benzene-was known to affect human health; the uncertainty stemmed from the "difficulty in understanding, not to mention quantifying, that potential harm." 129 Therefore, as a requirement of Tonawanda's probation, the court ordered the company "to help community members understand the effects-or lack thereof-of the pollutants to which they have been exposed" by funding the two informational studies. ${ }^{130}$

In other words, Tonawanda Coke was ordered to fund these studies as part of the company's sentence for its criminal violations of federal statutes. I call this "collateral monitoring." Key to this case, benzene was already regulated under federal environmental statutes. ${ }^{131}$ And, the company's particularly egregious violations of these statutes, which greatly increased plaintiffs' exposure, gave the court license to fashion a unique remedy that also generated valuable information. Like DuPont's funding of the epidemiological studies on exposure to $\mathrm{C}-8$, these studies have the potential to increase information about benzene exposure..$^{132}$

Courts should order such collateral monitoring more often and regularly include this type of "community service" when fashioning sentences for criminal violations that involve large-scale population exposure to regulated substances. But such court-ordered collateral monitoring is limited when tied to criminal behavior; such egregious violations of federal environmental statutes are rare. Moreover, this kind of violation-based informational remedy would not be available for exposures to unregulated (and unstudied) substances, for which risk information would be most valuable.

A remedy of informational monitoring would have a far greater impact if it could be tied to a tort like trespass that results in exposure to an unstudied substance instead of tied to criminal liability. The next Section proposes the equivalent of such broad collateral monitoring,

128. Tonawanda, 5 F. Supp. 3d at 361-63 (citing Friends of the Earth v. Gaston Copper Recycling Corp., 204 F.3d 149, 160 (4th Cir. 2000); Mountain States Legal Found. v. Glickman, 92 F.3d 1228, 1234-35 (D.C. Cir. 1996); Vill. of Elk Grove Vill. v. Evans, 997 F.2d 328, 329 (7th Cir. 1993); Nw. Envtl. Def. Ctr. v. Owens Corning Corp., 434 F. Supp. 2d 957, 963 (D. Or. 2006)).

129. Tonawanda, 5 F. Supp. $3 d$ at 362-63.

130. Id. at 363 .

131. The district court noted that the fact that the pollutant is regulated lends support to the view that the community's concerns are reasonable. Id. at 362 ("Further, the enactment by Congress of laws governing emissions and other contaminants, and the participation by the United States in related international agreements, also weigh against any suggestion that the threatened harm is entirely chimerical.") (internal quotations omitted).

132. In fact, one of Tonawanda Coke's challenges to this aspect of its sentence was that it forces the company to basically generate "incriminating" evidence against itself by monitoring the nearby population and helping to establish evidence of specific causation. 
framed as a stand-alone tort cause of action instead of as an equitable remedy to the defendant's tortious conduct in exposing the plaintiff to the substance. ${ }^{133}$

\section{A New Tort Cause of Action for Monitoring}

Another option is for the common law to develop an explicit cause of action for informational monitoring and analysis exactly when little is known about the eventual harms, subject to appropriate limitations. This idea is not so far-fetched. This cause of action would be, in some ways, similar to a cause of action (or equitable remedy) for medical monitoring. Medical monitoring emerged to solve a perceived problem in addressing and mitigating likely future harms when we know that exposure significantly increases their likelihood of manifesting. A claim for informational monitoring or analysis could emerge to solve a related but distinct problem of generating information on causation when no information is currently available. ${ }^{134}$ Of course, it would not be justified by its role in promoting diagnosis or mitigation as medical monitoring is justified; it would be justified by its role in increasing our knowledge of harms and causation. ${ }^{135}$ In other words, instead of demonstrating that risk mitigation would be worthwhile, ${ }^{136}$ plaintiffs would be required to demonstrate that information generation would be worthwhile.

\section{a. Defining the Cause of Action}

Of course, the cause of action would have to be well-defined, with important limitations and constraints, in order to increase the likelihood of its generating useful information. Figure 1 presents one proposal to define and limit such a cause of action. Plaintiffs would have

133. This framing should not make a difference if the limitations are the same, and courts could be free to consider informational monitoring as a stand-alone tort or as an available equitable remedy under some circumstances. In the context of medical monitoring, for example, some states permit a cause of action for monitoring, while other states only allow medical monitoring as a remedy for an existing common law or statutory tort. See Aberson, supra note 21, at 1114 (noting these differences).

134. Professor Kenneth Abraham has previously acknowledged that claims for medical monitoring could potentially play a distinct role in helping plaintiffs establish specific causation in later tort litigation. See Kenneth S. Abraham, Liability for Medical Monitoring and the Problem of Limits, 88 VA. L. REv. 1975, 1978 (2002) ("A second, and quite different, conception of medical monitoring does not see it as a distinct form of liability for the tortuously inflicted economic cost of mitigation, but as a step in the development of evidence for use in subsequent action by plaintiffs seeking recovery for actual harm from the defendant.").

135. Id. at 1977-78.

136. A demonstration that, in most states, requires plaintiffs to show that their exposure put them at a significant increased risk of developing a particular injury for which beneficial treatment exists. 
to show that they were exposed to a specific substance due to the defendant's tortious conduct (based in, say, trespass, nuisance, or negligence) and that there exist no studies on the potential harm of the particular substance. Notably, this claim would be available both when plaintiffs allege present injury and when they do not. At any given point, some injuries may have already manifested while others are still dormant. To maximize the informational value of analysis and monitoring, it does not make sense to split plaintiffs into separate categories based on the timing of the lawsuit. Rather the analysis and monitoring would take account of the varying levels and extent of exposure and the current manifestation of injury.

Plaintiffs' satisfaction of this burden of production would give rise to an inference that court-ordered informational analysis and monitoring would be worthwhile in this case. The defendant could rebut the plaintiffs' showing by revealing any information it has on the potential harm or safety of the substance-and that information would be analyzed for its reliability. If the defendant provides no additional information, then the plaintiffs would obtain an equitable remedy for the unstudied exposure: the establishment of a scientific panel, paid for by the defendant, to analyze and monitor plaintiffs' exposure and health data. ${ }^{137}$ If appropriately implemented, such a cause of action could serve a valuable information-generating function in an age where science and data increasingly matter in law and policy. ${ }^{138}$

137. I do not advocate for lump-sum damages because the point is to actually do the analysis and monitoring. The Supreme Court has already rejected a claim for lump-sum costs in the medical monitoring context. See Metro-N. Commuter R.R. Co. v. Buckley, 521 U.S. 424, 440 (1997). Instead, my proposal advocates the creation of a court-administered fund to pay an expert panel to analyze and monitor health information. See Exxon Mobil Corp. v. Albright, 71 A.3d 30, 82 (Md. 2013) (describing how such a fund can be administered).

138. The benefits include generating information on the level of optimal care and promoting better regulation. See discussion supra Part II. 
Figure 1. Defining and Distinguishing A New Cause of Action for Informational Analysis and Monitoring

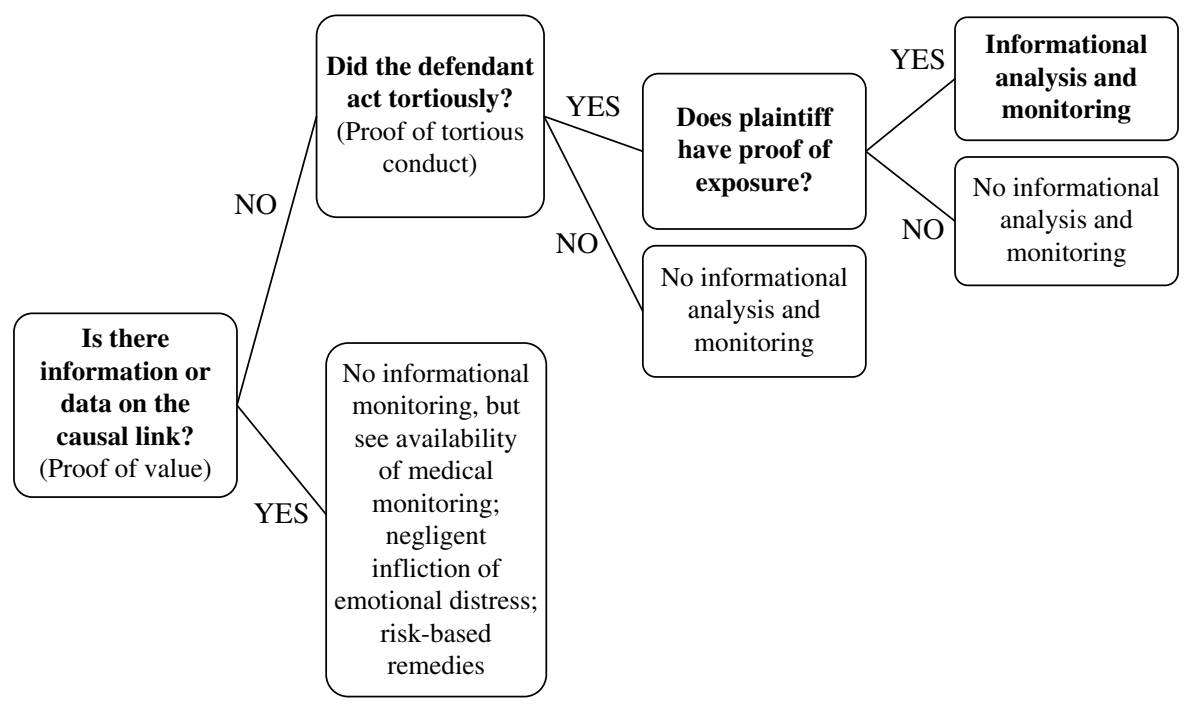

Importantly, the plaintiffs do not directly receive any monetary damages. The relevant injury is the exposure to an unstudied substance-and the remedy is funding to study the substance's long-term effects. The plaintiffs' payoffs, then, are (1) the identification of harms through analysis and monitoring, and (2) if exposure is found to increase the probability of specific harms, the creation of scientific evidence that can be used in future claims for plaintiffs who manifest these harms. ${ }^{139}$ The other beneficiaries of the cause of action are the chosen scientific researchers, who would get funding for the specific studies, and society at large, which benefits from additional information on whether substances are harmful or not. As the DuPont and Tonawanda Coke cases demonstrate, courts have been capable of organizing and directing defendants' money for research or scientific purposes. Other examples include cases where courts have directed a portion of punitive damages to particular charities or research founda-

139. There may be multiple firms that use the relevant unstudied substances. Jurisdictions could vary as to whether other defendants could join others in the action so that they could contribute to funding the monitoring and analysis. Such joinder makes most sense where exposure is not tied to a particular defendant's negligent handling or disposal of the substance but rather related to common uses of the substance, such as when customary handling or disposal is found to leak or seep into others' property. See, e.g., Sindell v. Abbott Labs., 26 Cal. $3 d 588$ (1980). At least, contribution to the research fund could vary based on the degree of a defendant's culpability. Federal regulation could keep track of users of unstudied substances. 
tions. ${ }^{140}$ Unlike undirected general scientific research, the questions that are funded are plaintiff-initiated, focusing efforts on scientific gaps about which real people are concerned. ${ }^{141}$

But in order to ensure that the data is reliable, any resulting informational analysis or monitoring must include a large enough exposed population and control population. ${ }^{142}$ In the DuPont and Tonawanda Coke cases, the potential for useful information was high because the court's action motivated health analysis and monitoring of large populations - the users of contaminated water systems in one and the entire nearby population in the other. As discussed in Part I, analyzing the medical history or ordering the medical monitoring of one individual is unlikely to generate useful information about general or specific causation, and creating and allowing a new cause of action for such a purpose would not be justified. ${ }^{143}$ The monitoring and analysis, then, would necessarily extend beyond the plaintiffs in any given case. The agreed-upon researchers would develop the study design and recruit suitable exposed and control participants to maximize useful information for the plaintiffs and the public.

In an ideal case, a large exposed population would join together in a class action, reducing the cost of identifying and recruiting exposed participants for analysis and monitoring. In the cause of action proposed in this Article, ${ }^{144}$ plaintiffs would have to show three elements: (1) no reliable epidemiological information exists, (2) plaintiffs were exposed to the substance, and (3) defendant's tortious conduct caused the exposure. The first element would be easy to demonstrate on a class-wide basis. ${ }^{145}$ The second element would likely require some type of blood testing to show exposure, ${ }^{146}$ while the third element

140. See, e.g., Dardinger v. Anthem Blue Cross \& Blue Shield, 781 N.E.2d 121, 145 (Ohio 2002) (directing about two-thirds of the plaintiff's punitive damages to a cancer research fund established by the court). See also Catherine M. Sharkey, Punitive Damages As Societal Damages, 113 YALE L.J. 347, 387 (2003) (discussing diversion of punitive damage awards for general social-welfare ends).

141. This would be true even if the litigation is organized and financed by an outsider, as the outsider would only be willing to do this if potential gains exist. The potential gains would be the expected value of the information in forming the basis for further recovery.

142. See Abraham, supra note 134, at 1985 (arguing that "the most significant difference between the mitigation and evidentiary development perspectives turns on whether there must be a critical mass of plaintiffs to support a medical monitoring claim").

143. Id. at $1985-86$.

144. See supra Figure 1.

145. Although I propose allowing this cause of action whenever there is no reliable epidemiological data, it is possible to require some showing of potential harm, such as some animal bioassay or other evidence showing a link between the substance and some harm.

146. I propose a limiting requirement of a physical (biological) showing of exposure to the substance. Alternatively, a court could require a less precise showing of exposure at this stage- 
would require showing that the defendant's actions in exposing plaintiffs to the substance could be considered tortious ${ }^{147}$ under theories of negligence, ${ }^{148}$ nuisance, or trespass. ${ }^{149}$ These latter two elements might be more difficult to demonstrate on a class wide-basis. ${ }^{150}$ But in the case of monitoring and analyses, research studies would benefit from large groups of people with varying levels of exposure.

\section{b. Considering Objections}

This new cause of action might appear radical, but it is not much different in form than claims for medical monitoring and equitable remedies that courts apply in other circumstances. And in this case, the benefits would extend beyond benefits for individual plaintiffs. Nonetheless, it is important to consider potential unintended consequences and, more generally, to compare this kind of solution to other reasonable alternatives.

One often-cited unintended consequence of creating the related tort for medical monitoring is the potential to flood the courts with frivolous actions from uninjured (and therefore lower-priority) plaintiffs, diverting resources away from injured plaintiffs. ${ }^{151}$ The concern

such as a proximity rule (within a defined area) or a property rule (substance on plaintiffs' land or groundwater).

147. The idea here is to limit the cause of action to unconsented exposures.

148. Negligence would include negligence per se, taking advantage of a regulatory violation similar to the violations in the case study on the Tonawanda Coke Corporation. But it is possible to allow plaintiffs to simply allege negligence in exposing them to an unstudied substance that may cause future harms. This would create a low, but not entirely unprecedented, bar to satisfying the element. It would be similar to the showing necessary for a medical monitoring cause of action in many states. See also Abraham, supra note 134, at 1986 (justifying imposing medical monitoring costs on the defendant "because the defendant has created a situation in which issues of disease or injury causation may arise in the future" and therefore "should be responsible for the costs of its collection").

149. A trespass-based cause of action would tie the plaintiffs' exposure to the substance on their property as a result of the defendant's discharge of the substance.

150. Take exposure. In one case, a federal court required blood tests from all potential class members in order to demonstrate sufficient and similar class-wide exposure prior to class certification in a standard toxic torts case. See Rhodes v. E.I. DuPont de Nemours \& Co., 253 F.R.D. 365, 375 (S.D.W. Va. 2008). See also Edward Casmere et al., Toxic Torts and Environmental Law, 49 TORT Trial \& Ins. Practice L.J. 453, 459 (2013). But, in a cause of action for informational monitoring and analysis, the relevant common feature in this cause of action is exposure to an unstudied substance; the degree of exposure is not relevant, and, in fact, research studies will benefit from including individuals with varied levels of exposure. In addition, testing of a representative sample could be allowed to balance the need for biomonitoring data on exposure before certification and the cost of this data collection. See Hall, Iles \& Morello-Frosch, supra note 1 , at 45 (proposing a sampling solution for medical-monitoring class actions). Alternatively, the defendant could reimburse costs.

151. See Caronia v. Philip Morris USA, Inc., 22 N.Y.3d 439, 451 (2013) (declining to create a cause of action for medical monitoring in part to prevent " 'tens of millions' of potential plaintiffs [from] recover[ing] monitoring costs, effectively flooding the courts while concomitantly 
in the informational analysis and monitoring context could be described as two-fold: (1) the defendant has limited resources, and it should not spend them on information generation, leaving fewer resources available for plaintiffs that manifest injuries; and (2) the court has limited resources, and it should not use its resources to preside over causes of actions brought by plaintiffs with speculative injuries.

The first concern relates to defendant's limited resources. As discussed, reliable epidemiological analysis and monitoring would cost millions. Through a new tort cause of action, plaintiffs would get defendants to pay for this analysis and monitoring. But, the argument goes, such liability for analysis and monitoring might bankrupt the defendant and result in insufficient assets to pay for any actual harms. In other words, instead of compensating those plaintiffs that are actually injured, the defendants' resources were misallocated to paying for mostly frivolous claims. In the case of Tonawanda Coke, the potential for bankruptcy as a result of the informational studies proved true; the company filed for bankruptcy in fall 2018. ${ }^{152}$

But in the absence of this information, plaintiffs that are actually injured by the defendant would likely be unable to bring viable claims for reasons discussed in Part I. The true comparison, then, is between generating this information and possibly bankrupting the defendant and not generating this information and staying the defendant's bankruptcy but potentially harming plaintiffs. In industries where insolvency due to this new liability is most likely, there is reason to think that incentivizing the generation of information is more valuable. Professor Steven Shavell has argued that regulation is preferable when the actors causing risk might have insufficient assets to pay for the resulting harm. ${ }^{153}$ But in order to set regulation at an optimal level, risk information is especially important. This means that, especially for industries at risk of becoming bankrupt, producing information about risk is to very valuable-likely more valuable than protecting the company's limited ability to pay out some future claims if harms

depleting the purported tortfeasor's resources for those who have actually sustained damage"); James A. Henderson, Jr. \& Aaron D. Twerski, Asbestos Litigation Gone Mad: Exposure-Based Recovery for Increased Risk, Mental Distress, and Medical Monitoring, 53 S.C. L. REv. 815, 850 (2002) (arguing that the "massive number of uninjured claimants presenting anticipatory claims" could "devour[ ] the defendants' resources," forcing them into bankruptcy).

152. Tonawanda Coke went bankrupt before it could pay out the last $\$ 2$ million of the $\$ 12$ million required for the studies. See Telvock, supra note 23.

153. Shavell, supra note 33 , at 361-62. 
manifest and plaintiffs are able to bring claims. The information could lead to regulation that would promote optimal risk mitigation. ${ }^{154}$

The second concern relates to the proper allocation of judicial resources. As an initial matter, it is not clear that the courts' time is most valuably spent compensating injured plaintiffs as compared to incentivizing the generation of information on harms. ${ }^{155}$ Nonetheless, the concern that this cause of action could give rise to a flood of claims that will overwhelm limited judicial resources is not far-fetched. Some have observed that courts that have allowed recovery for medical monitoring were hit with an "avalanche of claims." 156 In fact, part of this Article's motivation is that there are more than 80,000 substances on the TSCA inventory for which there is no reliable information on harms. But, through clear limits on the availability of the cause of action, a court can exert control over the number of cases that can be brought. This Article proposed one way to define this tort, but, as summarized in Table 1 and noted in several footnotes, ${ }^{157}$ there are ways to expand or limit the cause of action from this particular proposal. And, as defined here, the plaintiffs would receive only the equitable remedy of monitoring and analysis; there would be no additional compensation for emotional harm from the unstudied exposure. The limited remedy should reduce concerns about plaintiffs seeking out windfall damages.

In addition, as time goes on, there would presumably be fewer substances that meet the trigger of insufficient information, in part because of successful litigation and in part because some firms might choose to proactively generate their own data on long-term harms. Of course, the equitable remedy provided for could increase administrative burdens on the court, at least in the short run. It is reasonable to expect, however, that current scientific institutions would adapt to better provide the administrative and research support necessary to maintain these claims. Overall, whether we think courts should allocate some of their resources to this role depends in part on whether we think there exist better alternatives to generating this information.

154. Of course, it is still important to consider whether this information should be generated through a tort vehicle versus a regulatory vehicle. The next Part considers regulatory vehicles.

155. Ideally, state legislatives could make these difficult policy judgments and decide whether and to what extent such claims should be allowed in courts.

156. See Victor E. Schwartz, Leah Lorber \& Emily J. Laird, Medical Monitoring: The Right Way and the Wrong Way, 70 Mo. L. Rev. 349, 382 (2005).

157. See supra notes 144-49 and accompanying text; see also infra Table 1. 
TABLe 1. Options for Defining A Claim for Informational

Analysis and Monitoring

\begin{tabular}{|l|l|}
\hline THIS PROPOSAL & \multicolumn{1}{c|}{ NOTES AND VARIATIONS } \\
\hline $\begin{array}{l}\text { (1) No reliable } \\
\text { epidemiological } \\
\text { information exists. }\end{array}$ & $\begin{array}{l}\text { I propose allowing this cause of action } \\
\text { whenever there is no reliable epidemiological } \\
\text { data. } \\
\text { Other options: some evidence of potential } \\
\text { harm, such as suggestive animal bioassays } \\
\text { (narrower) }\end{array}$ \\
\hline $\begin{array}{l}\text { (2) Plaintiffs were } \\
\text { exposed to the } \\
\text { substance. }\end{array}$ & $\begin{array}{l}\text { I propose a requirement for evidence of } \\
\text { physical/biological exposure- e.g., } \\
\text { biomonitoring/blood tests - but no } \\
\text { requirement for other present injury. } \\
\text { Other options: a proximity rule (within a } \\
\text { defined area) (broader); a property rule } \\
\text { (evidence of substance on plaintiffs' land or } \\
\text { groundwater) (broader); significant exposure } \\
\text { (narrower); some evidence of present injury } \\
\text { (narrower) }\end{array}$ \\
\hline $\begin{array}{l}\text { (3) Defendant's } \\
\text { tortious conduct } \\
\text { caused the } \\
\text { exposure. }\end{array}$ & $\begin{array}{l}\text { I propose a requirement that defendant's } \\
\text { conduct was tortious in some way. } \\
\text { Other options: no requirement (more likely to } \\
\text { include torts based on consensual exposures); } \\
\text { require some regulatory violation (narrower) }\end{array}$ \\
\hline
\end{tabular}

\section{Regulatory Fixes}

Alternatively, regulation can ensure that information on potential harms is consistently collected and analyzed. For example, the Comprehensive Environmental Response, Compensation, and Liability Act (CERCLA) already tries to address data gaps in several ways for substances identified as hazardous. Below I discuss how federal and state governments can better address these gaps through statutory and regulatory law, drawing lessons from CERCLA.

First, Congress could strengthen federal requirements under TSCA for generating information about risks, requiring firms to monitor and analyze effects whenever they detect a release of an unstudied substance into the environment or whenever litigation alleging harm from the substance commences. These triggers for informational monitor- 
ing and analysis of populations would balance the benefits of allowing new products and processes on the market before extensive long-term analysis of their effects with the costs of persistent knowledge gaps on effects. ${ }^{158}$ In a way, this kind of a requirement would authorize by statute a form of the informational monitoring described in Part II. In fact, TSCA can explicitly enforce such a requirement through the courts as does CERCLA. In particular, under CERCLA, anyone who transports hazardous substances is liable for health assessments of affected persons. ${ }^{159}$ Typically, defendants pay for government-led research on potential harms from the exposure to the hazardous substances. ${ }^{160}$ In some circumstances, courts have also allowed private actions for medical monitoring for releases that would trigger CERCLA cleanup liability. ${ }^{161}$ Ideally, firms that use unstudied substances would also be required to post a bond or obtain insurance coverage for future monitoring and analysis should those responsibilities be triggered. ${ }^{162}$

Second, federal and state governments could expand funding for scientific research into links between harms and substances. Such programs could be modeled after CERCLA's Agency for Toxic Substances and Disease Registry (ATSDR), which was established to protect "communities from harmful health effects related to exposure to natural and man-made hazardous substances." 163 The ATSDR focuses on the risks of releases of known hazardous substances and Superfund sites, ${ }^{164}$ but there is no reason that it or a similar agency cannot examine the risks of unstudied substances used in production more broadly, given sufficient funding. The ATSDR is funded by responsible parties under CERCLA; any similar agency for unstudied

158. Of course, firms could always choose to do more analysis before deployment of new products and processes.

159. See 42 U.S.C.A. § 9607(a)(4)(D) (West 2016) (stating, under recoverable costs and damages, that "any person who accepts or accepted any hazardous substances for transport . . . is liable for ... the costs of any health assessment or health effects study carried out under section 9604(i) of this title").

160. See id. § 9604(i) (describing the work of the Agency for Toxic Substances and Disease Registry).

161. See Giovanni v. United States Dep’t of Navy, 906 F.3d 94, 110 (3d Cir. 2018) (considering plaintiffs' requests for medical monitoring as separate from the remedial actions under CERCLA).

162. This would be especially important for small, undercapitalized firms that use such substances.

163. See 42 U.S.C. $§ 9604(i)$ (West 2016); Agency for Toxic Substances and Disease REGISTRY, https://www.atsdr.cdc.gov/ (last visited Jun 15, 2018) [hereinafter ATSDR Website].

164. ATSDR Website, supra note 163; see also Kristen Chapin, Toxic Torts, Public Health Data, and the Evolving Common Law: Compensation for Increased Risk of Future Injury, $13 \mathrm{~J}$. Energy NAt. Res. \& EnVtL. L. 129, 132-33 (1993). 
substances should also have a specified funding source. One option is to have firms that violate any environmental regulations pay into the fund. But this would displace whatever use states currently make of these fines, and it might not provide sufficient funding. Another option is to have firms pay into the fund whenever they are found to be responsible for a release of any unstudied substance. Alternatively, the program could be linked to successful causes of action for informational monitoring and analysis discussed in Part II. The state agency would coordinate the informational monitoring, thereby reducing the administrative costs of the tort option.

\section{CONClusion}

For many substances, there is no reliable information on their potential to cause harm. But such information is required before regulatory, tort, or other risk-management schemes can function efficiently. Individuals increasingly care about understanding the potential for various substances to cause harm, but there are significant hurdles to developing this information. This Article proposes a new tort cause of action that would require firms that use such substances to, under some circumstances, fund the informational analysis and monitoring of harms to exposed populations. In particular, plaintiffs would have to show that they were exposed to a specific substance due to the defendant's tortious conduct and that there exist no reliable studies on the potential harm of the particular substance. This showing would give rise to a rebuttable presumption that court-ordered informational analysis and monitoring would be worthwhile in this case. A successful claim would lead to the establishment of a scientific panel, paid for by the defendant, to analyze and monitor plaintiffs' exposure and health data along with data from relevant control populations. The resulting epidemiological information would make future regulation better and future litigation more efficient. Such a limited tort cause of action for informational analysis and monitoring could help society whittle away at the list of more than 80,000 substances for which we have no reliable information about harms. 